\title{
Contribution of insulin-like growth factor (IGF)-I and IGF-binding protein-3 to mitogenic activity in bovine mammary extracts and serum
}

\author{
M S Weber ${ }^{1}$, S Purup, M Vestergaard, S E Ellis ${ }^{1}$, \\ J S\$ndergård-Andersen ${ }^{2}$, R M Akers ${ }^{1}$ and K Sejrsen \\ Department of Animal Nutrition and Physiology, Danish Institute of Agricultural Sciences, Foulum, DK-8830 Tjele, Denmark \\ ${ }^{1}$ Department of Dairy Science, Virginia Polytechnic Institute and State University, Blacksburg, Virginia 24061-0315, USA \\ ${ }^{2}$ Department of Analytical Chemistry, Novo Nordisk A/S, DK-3250, Gentofte, Denmark \\ (Requests for offprints should be addressed to R M Akers)
}

\begin{abstract}
Peripubertal development of the mammary gland is probably mediated by locally produced growth factors acting in concert with circulating mitogens. Our objective was to investigate the effect of recombinant human insulin-like growth factor-binding protein-3 (rhIGFBP-3) or insulin-like growth factor-I (IGF-I) antibodies on the IGF-I-related mitogenic activity of bovine serum and of mammary tissue extracts in primary mammary epithelial cell cultures. Cells were obtained from prepubertal female calf mammary tissue and cultured in three-dimensional collagen gels. An aqueous mammary parenchymal tissue extract (pooled from 20 prepubertal heifers) or serum (pooled from 3 heifers) at a concentration of 5\% was added to the medium containing either rhIGFBP-3 or monoclonal or polyclonal antibodies to human IGF-I. Cell proliferation was evaluated using $\left[\right.$ methyl- $\left.{ }^{3} \mathrm{H}\right]$ thymidine
\end{abstract}

incorporation as a measure of DNA synthesis. Addition of mammary extracts stimulated DNA synthesis 545\% compared with basal medium. Addition of serum stimulated DNA synthesis by $28 \%$. Mitogenic activity of serum and added IGF-I was abolished by addition of rhIGFBP-3 in equimolar concentrations with IGF-I. For mammary extracts, mitogenic activity was inhibited by $35 \%, 50 \%$, and $82 \%$ by the addition of rhIGFBP-3 at, respectively, 1 , 2 and 4 times the molar IGF-I concentration in the extract. Addition of rhIGFBP-3 to basal medium reduced DNA synthesis by $26 \%$, whereas IGF-I antibodies had no consistent effect. These results indicate that circulating and mammary-synthesized IGF-I and IGFBPs probably play a critical role in prepubertal development of the bovine mammary gland.

Journal of Endocrinology (1999) 161, 365-373

\section{Introduction}

Regulation of mammary growth and development is accomplished by a complex interplay of circulating hormones with locally acting growth factors. Classic studies in laboratory and domestic species established the involvement of hormones from the ovary and pituitary gland in hormonal control of mammary development (Forsyth 1991). Subsequent investigations into the mechanisms underlying the effects of these hormones on mammary cell growth revealed the existence of potent systemic as well as mammary-derived growth factors that may mediate much of their activity (Oka et al. 1991). Moreover, Waksman et al. (1991) demonstrated that tissue extracts from bovine pituitary, kidney, uterus and mammary gland stimulated mammary cell DNA synthesis in a dose-dependent manner and concluded that normal mammary epithelial cell proliferation is probably influenced by a multitude of tissue-derived growth factors.
Exogenous bovine somatotropin (bST) stimulates peripubertal mammary growth in dairy heifers (Sejrsen et al. 1986) and sheep (McFadden et al. 1990). However, much evidence indicates that bST functions by an indirect mechanism of action, mediated at least in part by insulinlike growth factor (IGF)-I (Akers 1985, Kleinberg 1997). The mitogenic effect of IGF-I on mammary explants (Baumrucker \& Stemberger 1989, Purup et al. 1995), or mammary organoids of bovine (Shamay et al. 1988, McGrath et al. 1991, Purup et al. 1995) and ovine (Winder et al. 1989) origin in collagen gel culture, and in mammary tissue of pregnant heifers (Collier et al. 1993) has been documented. In the mammary gland, IGF-I is synthesized locally by stromal tissue and is considered to act on adjoining epithelial cells via a paracrine mechanism of action (Cullen et al. 1992). It is likely that IGF-I of both systemic and local origins influences mammary cell proliferation, together with additional serum- and mammary-derived growth factors. 
The mitogenic activity of IGF-I is modulated in vivo by a family of IGF-binding proteins (IGFBP), which are secreted from mammary epithelial cells in culture (Campbell et al. 1991, McGrath et al. 1991). In the circulation, IGF-I associates predominantly with IGFBP-3. Production of IGFBP-3 by mammary epithelial cells is stimulated by IGF-I, indicating a potential mechanism for regulation of IGF-I activity (McGrath et al. 1991, Romagnolo et al. 1994). Thus, IGFBP-3 modulation of IGF-I mitogenic activity in mammary tissue may be important in normal growth and development of the mammary gland.

Our objective was to evaluate the potential importance of IGF-I and IGFBP-3 in serum and mammary tissue extract in stimulating mammary epithelial cell proliferation. This paper describes the modulatory effect of recombinant human (rh) IGFBP-3 and IGF-I antibody addition to cultures of primary undifferentiated mammary epithelial cells when supplemented with IGF-I, serum or mammary gland extracts from prepubertal heifers.

\section{Materials and Methods}

\section{Materials}

All reagents were of analytical grade unless otherwise stated. Recombinant human insulin-like growth factor-I (molecular weight $=7646 \mathrm{Da}$ ) was purchased from Bachem AG (Bubendorf, Switzerland). Glycosylated recombinant human IGFBP-3 (molecular weight $=47000 \mathrm{Da}$ ) was obtained from Upstate Biotechnology (Lake Placid, NY, USA). Rabbit anti-human IGF-I polyclonal antibody (immunoglobulin $\mathrm{G}(\mathrm{IgG})$ fraction) was purchased from Austral Biologicals (San Ramon, CA, USA). The mouse anti-human IGF-I monoclonal antibody was generously provided by Novo Nordisk A/S, Gentofte, Denmark. Mouse anti-human $\operatorname{IgG}$, deoxyribonuclease I (DNase), and type I-S hyaluronidase were obtained from Sigma (St Louis, MO, USA). Collagenase (type II; $273 \mathrm{U} / \mathrm{mg}$ ) was purchased from Worthington Biochemical Corp. (Freehold, NJ, USA). Fetal bovine serum (FBS) was purchased from Life Technologies (Gaithersburg, MD, USA). Basal medium was prepared by dissolving sodium bicarbonate $(24 \mathrm{mM})$ in water containing M-199 powder with Earle's salts, L-glutamine and Hepes buffer (Sigma, St Louis, MO, USA), medium was sterile filtered prior to adding sterile bovine serum albumin $(2 \cdot 6 \mathrm{~g} / \mathrm{l})$, transferrin (5 mg/l), reduced glutathione $(1 \mathrm{mg} / \mathrm{l})$, soybean trypsin inhibitor $(1 \mathrm{mg} / \mathrm{l})$, bovine insulin $(10 \mu \mathrm{g} / \mathrm{l})$, selenium $(1 \mu \mathrm{g} / \mathrm{l})$ and antibiotic solution $(0 \cdot 2 \%)$ containing penicillin $(50000 \mathrm{IU} / \mathrm{l})$ and streptomycin $(50 \mathrm{mg} / \mathrm{l})$ were added to the medium. [Methyl- ${ }^{3} \mathrm{H}$ ] thymidine (specific activity $3.03 \mathrm{TBq} / \mathrm{mmol}$ ) was obtained from Amersham International (Birkeröd, Denmark).

\section{Source of mammary extracts and serum}

Extracts were prepared from the mammary parenchyma of 20 prepubertal Friesian heifers (body weight and age at slaughter $237 \pm 7 \mathrm{~kg}$ and $272 \pm 4$ days respectively) that were part of a previous experiment (Vestergaard et al. 1995). At slaughter, mammary glands were removed and mammary parenchyma was excised from the left half of the udder and frozen at $-80{ }^{\circ} \mathrm{C}$. Aqueous mammary extracts were prepared from thawed tissue essentially according to Waksman et al. (1991). Frozen slices (5 g total) were cut from larger tissue samples and homogenized in physiological saline $(12 \mathrm{ml})$ for $1 \mathrm{~min}$ using a Polytron tissue homogenizer (Kinematica, Buch \& Holm, Herlev, Denmark). A saline rinse $(3 \mathrm{ml})$ of the Polytron tip was combined with the initial homogenate, and the total homogenate $\left(3: 1\right.$ saline to tissue) was shaken at $4{ }^{\circ} \mathrm{C}$ for $90 \mathrm{~min}$. Homogenates were then filtered through a double layer of surgical gauze, and the filtrate was centrifuged for $45 \mathrm{~min}$ at $10000 \mathrm{~g}$ at $4{ }^{\circ} \mathrm{C}$. The supernatant was recovered from below the uppermost fat layer and subsequently centrifuged at $105000 \mathrm{~g}$ for $1 \mathrm{~h}$ at $4{ }^{\circ} \mathrm{C}$. The supernatant was filtered through sterile $0 \cdot 2 \mu \mathrm{m}$ filters and stored at $-80{ }^{\circ} \mathrm{C}$. Protein content of the mammary extracts was determined using the bicinchoninic acid assay (Pierce Life Technologies, Roskilde, Denmark). The mammary extracts were pooled and used for the in vitro experiments. Serum for in vitro experimentation was obtained from 3 prepubertal Friesian heifers averaging $257 \pm 7$ days of age and $192 \pm 14 \mathrm{~kg}$ body weight.

\section{Primary cell preparation and culture}

Mammary epithelial cells were prepared from mammary parenchymal tissue from a prepubertal Friesian heifer (200 kg body weight, 242 days of age) essentially according to Shamay et al. (1988). Within $10 \mathrm{~min}$ of slaughter, mammary parenchyma was excised aseptically from the outer margin of the parenchyma and minced finely with scissors. Tissue pieces were transferred to a petri dish and weighed. Tissue was incubated in basal medium supplemented with DNase $(277 \mu \mathrm{g} / \mathrm{g}$ tissue $)$, insulin $(67 \mu \mathrm{g} / \mathrm{g}$ tissue) and an antibiotic-antimycotic mixture, at a ratio of $10 \mathrm{ml}$ medium per gram tissue, for $10 \mathrm{~min}$ in a $37^{\circ} \mathrm{C}$ shaking water bath. Tissue pieces were allowed to precipitate for $5 \mathrm{~min}$ and excess medium was aspirated. Tissue was then digested in basal medium supplemented with collagenase $(10 \mathrm{mg} / \mathrm{g}$ tissue), hyaluronidase $(10 \mathrm{mg} / \mathrm{g}$ tissue), DNase $(277 \mu \mathrm{g} / \mathrm{g}$ tissue) and insulin $(67 \mu \mathrm{g} / \mathrm{g}$ tissue), at a ratio of $10 \mathrm{ml}$ medium per gram tissue, for $5 \mathrm{~h}$ in a $37^{\circ} \mathrm{C}$ shaking water bath. Organoids were isolated by filtering the suspension through $200 \mu \mathrm{m}$ Nitex (Tetbo Co., Buancliff manoa, NY, USA) and centrifuging the filtrate for $10 \mathrm{~min}$ at $300 \mathrm{~g}$. Organoids were suspended in basal medium and allowed to precipitate for $8 \mathrm{~min}$; then excess medium was aspirated and replaced with fresh 
medium for a total of 10 washes. Following suspension in basal medium supplemented with 44\% FBS and 6\% dimethyl sulfoxide (DMSO), organoids were frozen overnight at $-80{ }^{\circ} \mathrm{C}$ and transferred the next day to liquid $\mathrm{N}_{2}$.

Collagen gels were prepared essentially as described by Shamay et al. (1988). A collagen solution prepared from rat tail tendons was neutralized using a neutralizing solution $(10 \times \mathrm{M}-199$ without bicarbonate and $0.33 \mathrm{M} \mathrm{NaOH}$ at a $2: 1$ ratio) at a ratio of about $6: 1$. Each well of 24-well plates (Nunc A/S, Roskilde, Denmark) was coated with $0.5 \mathrm{ml}$ of the neutralized collagen. Before use, organoids were quickly thawed at $37^{\circ} \mathrm{C}$ and washed in basal medium, then suspended in the cold neutralized collagen solution. The cell-collagen suspension $(0.5 \mathrm{ml})$ was pipetted onto each collagen gel and allowed to gel in a $37^{\circ} \mathrm{C}$ incubator for $30 \mathrm{~min}$ before $1 \mathrm{ml}$ basal medium was added. Cells were cultured for 5 days at $37^{\circ} \mathrm{C}$ in air: $\mathrm{CO}_{2}$ (95:5). Because treatments were distributed across multiple culture plates, the basal medium and 10\% FBS treatments were repeated four times in each experiment to evaluate consistency of treatment effects across different culture plates. Treatment media were added $24 \mathrm{~h}$ after plating and were changed every $48 \mathrm{~h}$.

\section{Thymidine incorporation}

Incorporation of [methyl- ${ }^{3} \mathrm{H}$ ] thymidine was determined essentially according to Shamay et al. (1988). On day 3 of culture, $50 \mu \mathrm{l}$ basal medium containing $20 \mathrm{mCi} / 1$ [methyl$\left.{ }^{3} \mathrm{H}\right]$ thymidine were added to each well. After $24 \mathrm{~h}$ incubation, media were aspirated from the wells and collagen gels were transferred to microcentrifuge tubes. Gels were dissolved by the addition of $150 \mu \mathrm{l} 25 \%$ acetic acid and subsequent incubation for $20-30 \mathrm{~min}$ at $37^{\circ} \mathrm{C}$. Cells were precipitated by centrifugation for $10 \mathrm{~min}$ at $500 \mathrm{~g}$. Following aspiration of the supernatant, $750 \mu \mathrm{l} \%$ perchloric acid (PCA) were added and tubes were centrifuged as above. Subsequent washes were performed similarly with $750 \mu \mathrm{l} 80 \%$ ethanol, 100\% ethanol and 4\% PCA. The final supernatant was aspirated and cells were hydrolyzed with $500 \mu \mathrm{l} 6 \% \mathrm{PCA}$ at $80{ }^{\circ} \mathrm{C}$ for $1 \mathrm{~h}$. The suspension was transferred to scintillation vials, mixed with $5 \mathrm{ml}$ scintillation fluid (Picofluor 40; Packard Instruments, Greve, Denmark) and counted in a liquid scintillation counter.

\section{Inhibition studies with IGFBP-3 and IGF-I antibodies}

For the purpose of IGFBP inhibition studies, it was assumed that binding reactions between IGF-I and rhIGFBP-3 are monovalent; that is, one molecule of IGF-I binds one molecule of rhIGFBP-3. Consequently, equimolar ratios of IGF-I and rhIGFBP-3 require that the weight concentration $(\mu \mathrm{g} / \mathrm{l})$ of rhIGFBP-3 be slightly more than sixfold greater than that of IGF-I $(47: 7 \cdot 6)$. For experiments utilizing addition of recombinant IGF-I, a concentration of $50 \mu \mathrm{g} / 1$ was utilized because this consistently corresponds with maximal responses in prior reports (Purup et al. 1995). Thus cultures containing $50 \mu \mathrm{g} / 1$ IGF-I were supplemented with $400 \mu \mathrm{g} / 1 \mathrm{rhIGFBP-3,}$ yielding an rhIGFBP-3:IGF-I ratio of approximately $1 \cdot 3$ (see Results section for other concentrations used).

For antibody inhibition studies, purity estimates supplied by the vendor were used to calculate molar ratio estimates. Assumptions were that each IgG molecule would bind one molecule of IGF-I, and that the average IgG molecule had a molecular weight of $120 \mathrm{kDa}$. Potential divalent binding of two IGF-I molecules, possible differences in classes of antibody molecules (polyclonal) present or possible differences in binding affinities were not considered.

For experiments with either rhIGFBP-3 or antibody addition, these components were combined with IGF-I, serum, or mammary extracts $2 \mathrm{~h}$ prior to addition to cultured cells as indicated. Concentrations of IGF-I in individual mammary extracts, and in serum obtained from three prepubertal heifers, were determined by an ELISA (OCTEIA IGF-I; ImmunoDiagnostic Systems Limited, Tyne and Wear, UK) that had been validated previously (Norup \& Vestergaard 1996).

\section{Ligand blotting}

Concentrations of IGFBPs in mammary extracts were evaluated by Western ligand blotting (Hossenlopp et al. 1986). Samples $(200 \mu \mathrm{g}$ protein; $17-31 \mu \mathrm{l}$ extract) from each of 20 heifers were dissolved in non-reducing SDSpolyacrylamide (SDS-PAGE) gel buffer, heated to $60{ }^{\circ} \mathrm{C}$ for $15 \mathrm{~min}$, and separated overnight on an SDSpolyacrylamide gel at constant current. Following transfer of proteins to a nitrocellulose membrane by electroblotting, the blots were incubated with $\left[{ }^{125}\right.$ I]IGF-I and washed. Autoradiographs from the blots were exposed at $-70{ }^{\circ} \mathrm{C}$ for 2 days.

\section{$\int^{125}$ I]IGF-I binding studies}

The amount of free IGF-I in media following a 2-h preincubation with a dilution series of rhIGFBP-3 or the polyclonal IGF-I antibody was evaluated by affinity labeling according to D'Ercole \& Wilkins (1984). $\left[{ }^{125}\right.$ I]IGF-I $\left(3.9 \times 10^{6}\right.$ c.p.m.; specific activity $\left.77 \mu \mathrm{Ci} / \mu \mathrm{g}\right)$ was incubated in $0.1 \mathrm{M}$ Dulbecco's phosphate-buffered saline, $\mathrm{pH} 7.5(400 \mu \mathrm{l}$ total) (Life Technologies, Grand Island, NY, USA) at $37^{\circ} \mathrm{C}$ for $2 \mathrm{~h}$ with rhIGFBP-3 or the polyclonal IGF-I antibody, at the same molar ratios used in cell culture. Investigation of tracer binding to rhIGFBP-3 or IGF-I antibody was performed by use of the crosslinking agent disuccinimidyl suberate (DSS; Pierce Chemical Co., Rockford, IL, USA) followed by SDSPAGE. Following a $2-\mathrm{h}$ preincubation period, samples (0.08-6.25 mg protein/l) were treated with $4 \mu \mathrm{l} 25 \mathrm{mM}$ DSS in DMSO (final concentration $0.25 \mathrm{mM}$ ) for $30 \mathrm{~min}$ 
at room temperature. Samples $(25 \mu \mathrm{l})$ were prepared for SDS-PAGE by addition of $25 \mu \mathrm{l}$ sample buffer ( $5 \%$ SDS, $10 \%$ glycerol, $0.06 \mathrm{M}$ Tris $-\mathrm{HCl} \mathrm{pH} \quad 6.8,5 \%$ 2-mercaptoethanol, and $0.02 \%$ bromophenol blue; final concentrations) and heated at $60{ }^{\circ} \mathrm{C}$ for $15 \mathrm{~min}$ (Hardouin et al. 1987). Free $\left[{ }^{125} \mathrm{I}\right] \mathrm{IGF}-\mathrm{I}$ was separated from bound $\left[{ }^{125}\right.$ I]IGF-I on a $10 \%$ polyacrylamide gel overnight at constant current. Autoradiographs from the gels were exposed at $-70{ }^{\circ} \mathrm{C}$ for $2 \mathrm{~h}$. The percentage of the total available $\left[{ }^{125}\right.$ I]IGF-I bound to rhIGFBP-3 or IGF-I antibody was calculated by gamma counting of the radioactivity in individual gel sections.

\section{Statistical analysis}

Statistical analyses were performed using the GLM procedure of SAS (SAS Institute, Inc. 1989). Significance of effects of factors added to media (in comparison with basal medium) was tested by analysis of variance followed by Dunnett's multiple comparison test. Comparisons with $P<0 \cdot 05$ were considered to be significantly different. Values are presented as least squares means (LS means) \pm s.E.M. of values obtained from triplicate samples.

\section{Results}

\section{Mitogenic activity}

To evaluate the contribution of IGF-I to mitogenic activity of mammary extracts and serum, primary bovine mammary organoids were embedded in attached collagen gels and grown for 4 days in treatment media. Organoids cultured with heifer serum consistently displayed a stellate appearance with broad outgrowths. In contrast, organoids cultured with mammary extracts, rIGF-I, or basal medium alone showed distinct needle-like projections. Figure 1A illustrates the dose-dependent effects on DNA synthesis of rhIGF-I in concentrations ranging from $3 \cdot 125$ to $100 \mu \mathrm{g} / 1$ during the final $24 \mathrm{~h}$ of a 4 -day treatment period $(P<0 \cdot 05$ at all concentrations compared with basal medium (0)). Similar to previous experiments, maximal stimulation of DNA synthesis was provided by approximately $25 \mu \mathrm{g} / 1$ IGF-I. Addition of $10 \%$ FBS stimulated DNA synthesis by 30\% (169 $979 \pm 24600$ d.p.m., $P<0 \cdot 05)$. The response to basal medium and 10\% FBS treatments did not differ according to position within the experiment $(P>0 \cdot 05)$, indicating that cell number per well and DNA synthesis were not affected by time of plating or harvest.

Addition of serum from prepubertal heifers to the culture medium stimulated cell proliferation at concentrations of $4 \%$ and greater $(P<0 \cdot 05)$ (Fig. 1B), with a dose-dependent response apparent over a range from 2 to $10 \%$ serum. As serum IGF-I concentration was $107 \mu \mathrm{g} / \mathrm{l}$, the increased DNA synthesis was apparent at an IGF-I concentration of $4 \cdot 3 \mu \mathrm{g} / 1$ in the medium ( $4 \%$ serum).
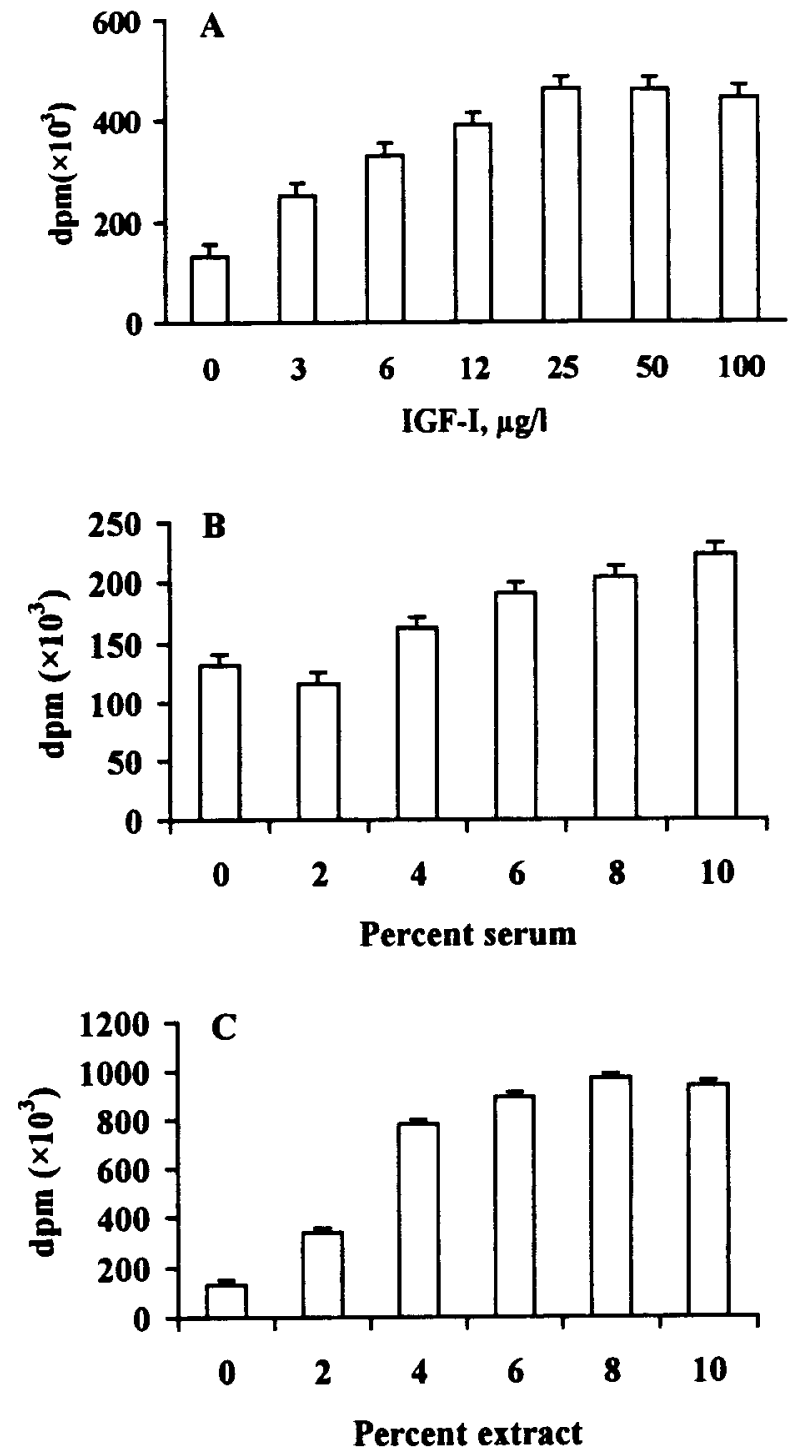

Figure 1 Effect of various concentrations of (A) rhIGF-I ( $\mu \mathrm{g} / \mathrm{l})$, (B) percent prepubertal heifer serum, or (C) percent mammary extract in culture medium on DNA synthesis (d.p.m.) in primary cultures of bovine mammary epithelial organoids. In A, B and C, the zero (0) level represents basal medium. Values are LS means \pm S.E.M. for cultures performed in triplicate.

Mammary extracts, on the other hand, stimulated cell proliferation much more potently than serum or IGF-I alone, yielding a mitogenic response more than twice that induced by the highest IGF-I concentration tested (Fig. 1C). The dose-dependent response was different from basal medium at all levels $(P<0 \cdot 05)$. Maximal stimulation of DNA synthesis occurred at a concentration between 6 and $8 \%$ of mammary extract in the culture medium. The IGF-I concentration within the mammary extract pool was $34 \cdot 0 \mu \mathrm{g} / \mathrm{l}$; thus, maximal cell proliferation 
was achieved at an IGF-I concentration of less than $3 \mu \mathrm{g} / 1$ in the medium. Of the IGFBP detected in mammary extracts, IGFBP-3 comprised $75 \%$ of the total, with lesser amounts of IGFBP-2 (7\%), a $28-\mathrm{kDa}$ species $(9 \%)$ and a $24-\mathrm{kDa}$ species $(9 \%)$ putatively corresponding to IGFBP-1 and IGFBP-4 (data not shown).

\section{Inhibition of mitogenic activity}

To investigate the contribution of IGF-I to mitogenic activity in serum and mammary extracts, rhIGFBP-3 and antibodies to hIGF-I were added to media containing either $50 \mu \mathrm{g} / \mathrm{l}$ of added rhIGF-I, $5 \%$ serum or $5 \%$ mammary extracts. These concentrations of serum and extracts were selected based on previous dose-response experiments resulting in approximately half-maximal responses. Addition of a low concentration of rhIGFBP-3 $(40 \mu \mathrm{g} / \mathrm{l})$ inhibited DNA synthesis in basal medium by $26 \%(P<0 \cdot 05)$, while addition of a higher concentration of rhIGFBP-3 $(800 \mu \mathrm{g} / \mathrm{l})$ reduced DNA synthesis in basal medium by $21 \%(P>0 \cdot 05)$ (Fig. $2 \mathrm{~A})$. Addition of monoclonal $(\mathrm{mAb})$ or polyclonal (pAb) IGF-I antibodies to cultures in basal medium did not show a consistent effect on DNA synthesis (Fig. 2B,C). Addition of a high concentration $(2000 \mu \mathrm{g} / \mathrm{l})$ of a non-immune IgG fraction inhibited DNA synthesis in response to basal medium $(P<0 \cdot 05)$ whereas a low concentration $(12.5 \mu \mathrm{g} / \mathrm{l})$ had no effect $(P>0 \cdot 05)$ (Fig. 2D).

With IGF-I-supplemented media, antibodies and rhIGFBP-3 were added at an antibody or IGFBP-3:IGF-I molar ratio of $1 / 16,1 / 8,1 / 4,1 / 2,1$, and 2 . Corresponding concentrations of rhIGFBP-3 in media were 25, 50, $100,200,400$ and $800 \mu \mathrm{g} / 1$. Similarly, antibody concentrations were $62 \cdot 5,125,250,500,1000$ and $2000 \mu \mathrm{g} / \mathrm{l}$. When added to medium supplemented with $50 \mu \mathrm{g} / 1$ IGF-I, equimolar and greater concentrations of rhIGFBP-3 reduced DNA synthesis to the level of basal medium $(P<0 \cdot 05)$ (Fig. 3). Monoclonal and polyclonal antibodies negated approximately $25 \%$ of the mitogenic activity of IGF-I when added at equimolar and greater concentrations $(P>0 \cdot 05)$.

To evaluate the effect of inhibition of IGF-I mitogenic activity on serum-induced cell proliferation, antibodies and rhIGFBP-3 were added at an antibody or rhIGFBP3:IGF-I molar ratio of 1/2, 1, 2 and 4 (Fig. 4A) in medium with $5 \%$ serum. Corresponding concentrations of rhIGFBP-3 in media were $20,40,80$ and $160 \mu \mathrm{g} / \mathrm{l}$. Antibody concentrations were 50, 100, 200 and $400 \mu \mathrm{g} / 1$. Addition of rhIGFBP-3 elicited a dose-related complete inhibition of the mitogenic activity at half the molar concentration of IGF-I and above $(P<0 \cdot 05)$. Addition of IGF-I antibodies or a non-immune IgG fraction did not significantly inhibit the mitogenic activity of serum $(P>0 \cdot 05)$.

Similarly, antibodies and rhIGFBP-3 were added with $5 \%$ mammary extracts at similar calculated antibody or
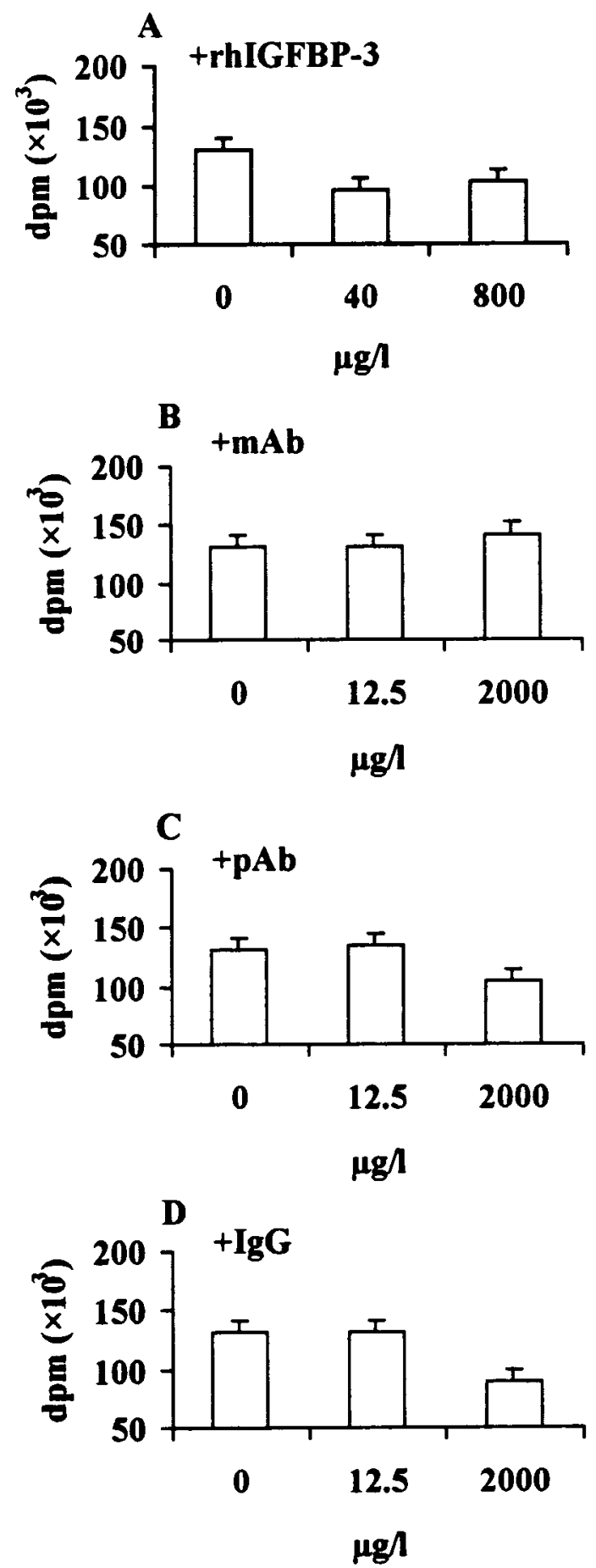

Figure 2 Effect of (A) rhIGFBP-3, (B) monoclonal $(+m A b)$ and $(C)$ polyclonal $(+p A b)$ IGF-I antibodies, and (D) a non-immune globulin (+ $\lg G)$ on DNA synthesis in basal medium (0).

Concentrations of added factors shown represent the lowest and highest amounts used in cultures. Values are LS means \pm S.E.M. for cultures performed in triplicate. 


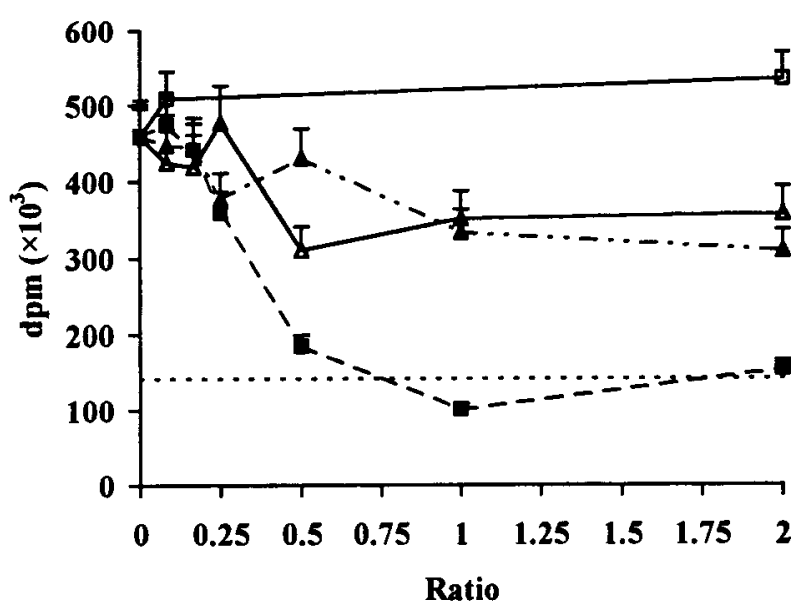

Figure 3 Inhibition of DNA synthesis (d.p.m.) in media containing rhIGF-I alone $(50 \mu \mathrm{g} / \mathrm{l})$ or with rhIGFBP-3 (ם), monoclonal (mAb)

$(\boldsymbol{\Delta})$ or polyclonal $(\mathrm{pAb})(\triangle)$ antibodies against IGF-I, or a non-immune globulin (IgG) ( $\square$ ). Concentrations are given as molar Ab/IGF-I, IGFBP-3/IGF-I or IgG/IGF-I ratios. The horizontal dotted line represents DNA synthesis in basal medium without IGF-I addition. Values are LS means \pm S.E.M. for cultures performed in triplicate.

rhIGFBP-3:IGF-I molar ratios as those given above (Fig. 4B). Corresponding concentrations of rhIGFPB-3 in media were $5,10,20$ and $40 \mu \mathrm{g} / 1$. Antibody concentrations were $12 \cdot 5,25,50$ and $100 \mu \mathrm{g} / \mathrm{l}$. Addition of rhIGFBP-3 inhibited cell proliferation at all levels $(P<0 \cdot 05)$. An equimolar concentration of rhIGFBP-3 abrogated $35 \%$ of the mitogenic activity in extracts, but the dose-dependent inhibition of rhIGFBP-3 was proportionally greater at $2(50 \%$ inhibition) and $4(82 \%$ inhibition) times the molar concentration of IGF-I. Addition of IGF-I antibodies inhibited up to one half of the mitogenic activity in mammary extracts.

\section{$\left[{ }^{125}\right.$ I]IGF-I binding studies}

The relative binding activity of rhIGFBP-3 and the IGF-I antibody $(\mathrm{pAb})$ for $\left[{ }^{125} \mathrm{I}\right] \mathrm{IGF}-\mathrm{I}$ was determined following a 2-h incubation, corresponding to time of treatment media addition to cell cultures. Complexes of rhIGFBP-3 and $\left[{ }^{125}\right.$ I]IGF-I or antibody and $\left[{ }^{125}\right.$ I]IGF-I were covalently bound using the cross-linking agent disuccinimidyl suberate and separated from free $\left[{ }^{125} \mathrm{I}\right] \mathrm{IGF}-\mathrm{I}$ by SDSPAGE. Samples containing rhIGFBP-3 and [ $\left.{ }^{125} \mathrm{I}\right] \mathrm{IGF}-\mathrm{I}$ exhibited one band corresponding to the protein complex that was not evident in a sample containing only $\left[{ }^{125} \mathrm{I}\right] \mathrm{IGF}-\mathrm{I}$, and one lower molecular weight band corresponding to free $\left[{ }^{125} \mathrm{I}\right] \mathrm{IGF}-\mathrm{I}$. This protein complex band increased in intensity in samples containing increasing concentrations of rhIGFBP-3, and there was a corresponding decrease in intensity of the free $\left[{ }^{125} \mathrm{I}\right] \mathrm{IGF}-\mathrm{I}$ band. At an IGFBP-3:IGF-I molar ratio of $1 / 8,1 / 2,1$, and 2 , the amount of bound $\left[{ }^{125} \mathrm{I}\right] \mathrm{IGF}-\mathrm{I}$ was, respectively, $4 \cdot 4,18 \cdot 0$,
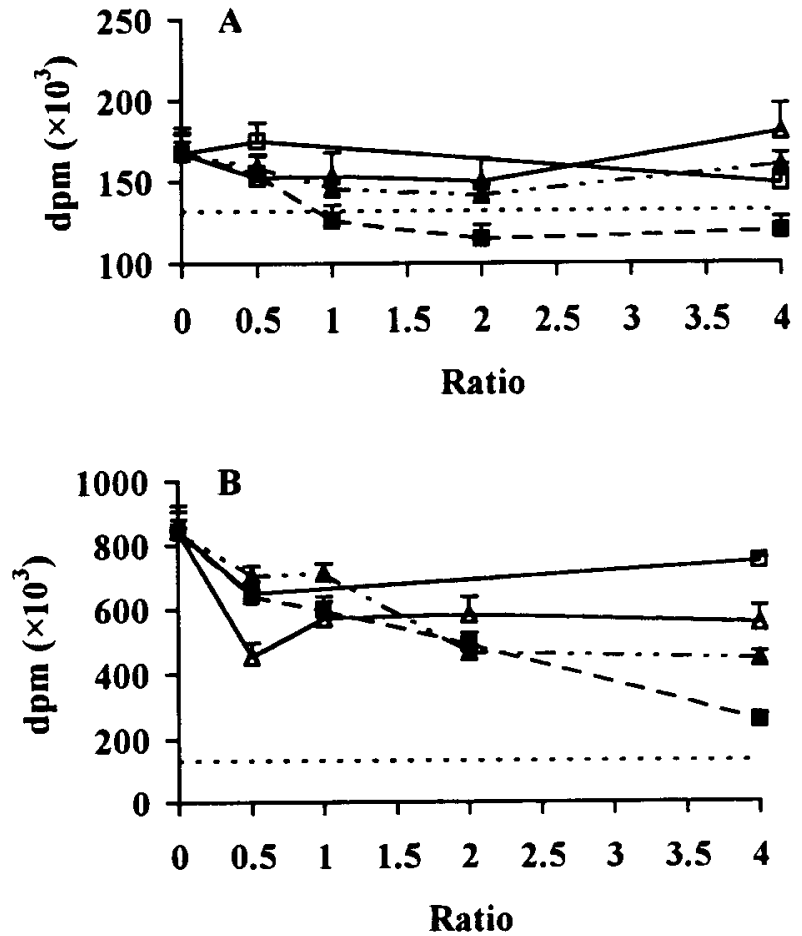

Figure 4 Inhibition of DNA synthesis (d.p.m.) in media containing (A) $5 \%$ heifer serum or (B) $5 \%$ mammary extracts alone or with rhIGFBP-3 ( $\mathbf{\square})$, monoclonal $(\mathrm{mAb})(\boldsymbol{\Delta})$ or polyclonal $(\mathrm{pAb})(\triangle)$ antibodies against IGF-I, or a non-immune globulin (IgG) ( $\square$ ). Concentrations are given as molar Ab/IGF-I, IGFBP-3/IGF-I or IgG/IGF-I ratios. The horizontal dotted line represents DNA synthesis in basal medium without $5 \%$ extracts added. Values are LS means \pm S.E.M. for cultures performed in triplicate.

$37 \cdot 9$, and $70 \cdot 4 \%$ of the total $\left[{ }^{125}\right.$ I]IGF-I available. Samples containing the IGF-I antibody and $\left[{ }^{125}\right.$ I]IGF-I did not show any bands corresponding to complexes of the antibody and $\left[{ }^{125} \mathrm{I}\right]$ IGF-I; only free $\left[{ }^{125} \mathrm{I}\right] \mathrm{IGF}-\mathrm{I}$ was detected. However, the presence of low amounts of an $\left[{ }^{125} \mathrm{I}\right] \mathrm{IGF}-\mathrm{I}$ and IGF-I antibody complex in the samples was detected by size exclusion chromatography and gamma counting of fractions (data not shown). All lanes displayed two minor bands corresponding to high molecular weights that were not consistently affected by the presence of rhIGFBP-3 or the IGF-I antibody. These bands probably resulted from nonspecific binding of $\left[^{125} \mathrm{I}\right] \mathrm{IGF}-\mathrm{I}$, possibly with bovine serum albumin in the $\left[{ }^{125}\right.$ I] IGF-I stock buffer. Regardless, the bands represented less than $2 \%$ of total counts in the incubation mixtures.

\section{Discussion}

Development of the mammary gland is probably influenced by multiple growth factors and their synergistic or antagonistic interactions (Oka et al. 1991, Forsyth et al. 1998). Many of these growth factors originate in the 
mammary gland and may act in an autocrine, juxtacrine or paracrine manner. Such factors also derive from other tissues and may reach the mammary gland via the circulation. In this experiment, mammary tissue extract was more mitogenic than heifer serum at a 10\% concentration in the culture medium, stimulating DNA synthesis by $618 \%$ and $70 \%$ respectively. This indicates that the bovine mammary gland is indeed a rich source of growth factors for mammary epithelium, as suggested by Sandowski et al. (1993). Of these factors, a potent mitogen for undifferentiated bovine mammary epithelial cells is IGF-I, which stimulated DNA synthesis approximately twofold in this study. In addition, the bovine mammary gland produces mRNA for transforming growth factor- $\alpha$ (Zurfluh et al. 1990, Koff \& Plaut 1995) which stimulates DNA synthesis in clonal (Woodward et al. 1994) as well as primary bovine mammary epithelial cells (Zurfluh et al. 1990). Also, expression of mRNA for IGF-II is developmentally regulated in mammary tissue of ewe lambs (Hovey et al. 1998) although IGF-II is considerably less mitogenic than IGF-I in vitro (Peri et al. 1992). Insulin alone can also stimulate proliferation of bovine undifferentiated mammary cells, although the insulin concentrations in individual mammary extracts composing the pooled stock in this experiment were undetectable.

From the present data, it is impossible to ascertain how much of this mitogenic activity in serum or extracts becomes directly available to mammary cells. Regardless, IGFs clearly contribute a portion of the mitogenic activity present, as equimolar concentrations of rhIGFBP-3 could inhibit approximately one third of the DNA synthesis stimulated by serum or extracts, presumably by binding IGF-I and thereby reducing its access to type I IGF receptors on mammary cells. The IGF-I antibodies were considerably less potent inhibitors of IGF-I bioactivity. Binding studies support the conclusion that this difference in inhibition is at least partially explained by the greater binding of rhIGFBP-3 to IGF-I. Similar to our results, a neutralizing monoclonal antibody to IGF-I was incapable of inhibiting IGF-I-induced $\left[{ }^{3} \mathrm{H}\right]$ thymidine incorporation in porcine granulosa cell cultures (Mondschein et al. 1989). The authors attributed this unexpected result, in part, to the moderate stimulation of $\left[{ }^{3} \mathrm{H}\right]$ thymidine incorporation by IGF-I alone. In our case, bovine primary mammary epithelial cells also secrete IGFBP-3 and IGFBP-2 in response to addition of IGF-I (M Weber, S Purup \& R M Akers, unpublished observations), which in cultures may compete with the added antibody for binding of available IGF-I. In this study, serum stimulated only a modest increase in $\left[{ }^{3} \mathrm{H}\right]$ thymidine incorporation, which was not inhibited by addition of the IGF-I antibodies. Along with the inherent difficulty in demonstrating inhibition of a slight growth response, it is possible that the IGF-I in the serum pool was less biologically available due to the presence of IGFBPs.

Similar to our present and previous results (Purup et al. 1995), Shamay et al. (1988) and Peri et al. (1992) showed that IGF-I at a low concentration is highly mitogenic for bovine undifferentiated mammary epithelial cells. Mammary IGF-I expression is low in comparison with the liver and other tissues (Forsyth 1996) but is potentially more meaningful in mammary development than systemic concentrations of IGF-I. For example, our recent data (Weber et al. 1998) demonstrate precocious alveolar bud formation in mammary glands of mouse mammary tumor virus (MMTV)-IGF-I transgenic mice, providing evidence that modulation of local mammary IGF-I can markedly alter prepubertal mammary development. In this study, the concentration of IGF-I in mammary extract $(34 \cdot 0 \mu \mathrm{g} / \mathrm{l})$ was approximately one third of that in serum $(107 \mu \mathrm{g} / \mathrm{l})$, yet the extract was nearly 20 times more mitogenic than serum. Interestingly, rhIGFBP-3 significantly reduced DNA synthesis in response to both serum and extracts. This suggests that the IGFs do provide a considerable portion of the mitogenic activity available in serum and mammary tissue extract. In ovarian granulosa cells, it has been suggested that the primary role of the IGFs is to amplify the actions of other hormones (Mondschein et al. 1989). Thus, the extent of IGF-I effects may be determined in large part by the influence of co-expressed factors in the mammary gland.

Such a dramatic difference in mitogenic activity between serum and mammary extracts may also derive from varying IGFBP profiles, or a lower concentration of free IGF-I in serum. The IGF-I molecule displays highaffinity binding to IGFBPs which regulate its bioactivity in a fashion that is not well characterized. Of these, IGFBP-3 is the predominant IGFBP in the circulation; furthermore, mRNA and protein for IGFBP-3 are more abundant than those for IGFBP-1 or IGFBP-2 in prepubertal bovine mammary tissue (Weber et al. 1996). The major difference in IGFBP profile between mammary extracts and serum of prepubertal heifers fed at a moderate feeding level is a two times higher relative abundance of IGFBP-2 in serum $(22 \%)$ compared with mammary extracts (10\%) (M Vestergaard, S Purup \& K Sejrsen, unpublished observations). The relationship of IGFBPs in serum and mammary tissue extracts from prepubertal heifers with DNA synthesis in primary cell cultures has been evaluated (Purup et al. 1999). Synthesis of DNA induced by $5 \%$ serum was negatively correlated with serum IGFBP-2 and positively correlated with serum IGFBP-3 and IGF-I. In multiple cell lines, IGFBP-2 has been shown to inhibit IGFdependent effects on cell growth as shown by addition of IGFBP-2 to cultures (Jones \& Clemmons 1995). In contrast, DNA synthesis in response to 5\% mammary extract was negatively correlated with IGFBP-3, while no significant correlation was observed between the growth response and IGFBP-2 or IGF-I. These results support the suggestion of Jones and Clemmons (1995) that circulating IGFBP-3 may stimulate IGF-I activity, while IGFBP-3 in mammary tissue may inhibit IGF-I activity. 
Differences in mitogenic activity between serum preparations may also be attributed in part to relative concentrations of different IGFBPs. In our study, 10\% heifer serum stimulated DNA synthesis to a greater degree than 10\% FBS. Analysis of IGFBPs was performed using serum from a representative set of heifers similar in age and body weight as well as rearing regimen to the three prepubertal heifers that supplied serum for these in vitro experiments. A higher proportion of the total IGFBP consisted of IGFBP-3 (72\%) compared with that in FBS $(13 \%)$. On the other hand, IGFBP-2 was more abundant in FBS (82\%) compared with the heifer serum $(22 \%)$. Taken together with the above correlations for serum IGFBP with DNA synthesis, these data indicate that the amounts of IGFBP-3 and IGFBP-2 present in serum preparations can contribute to different growth responses. For example, the mitogenic activity present in our IGF-I and FBS treatments appeared to differ from that reported by Shamay et al. (1988). In their study, IGF-I induced cell proliferation of only $25-40 \%$ of that achieved by addition of $10 \%$ FBS. In contrast, our results showed that maximal IGF-I stimulation was twice that induced by $10 \%$ FBS and were more in line with the comparatively greater IGF-I stimulation reported by Baumrucker \& Stemberger (1989) using prepartum and lactating mammary tissue. However, this difference with the results of Shamay et al. (1988) may also be related to the authors' comparison of the mitogenic activity of various FBS stocks and the ultimate selection of one exhibiting high activity (S Purup, personal communication). Clearly, the IGFBP present in serum in addition to IGF-I may contribute to a balance of positive and negative growth regulation.

Fibroblasts were not observed in culture experiments using our previously frozen cell preparations, lending further support to the earlier justification of this culture system for studying growth regulation of bovine mammary epithelium. The morphological appearance of growth observed during the culture period resembled the stellate and needle-like appearance of outgrowths described earlier (Shamay \& Gertler 1986). Interestingly, only organoids cultured with serum displayed the former phenotype, whereas added IGF-I and mammary extracts both induced distinct needle-like extensions from organoids. Taken together with the dramatic inhibitory effect of rhIGFBP-3 on DNA synthesis in response to mammary extracts, this observation indicates that IGF-I may supply a considerable portion of the mitogenic activity in mammary extracts.

In conclusion, these results suggest that the mammary gland is a rich source of mitogenic activity for developing mammary epithelium, in addition to the growth factors transported across mammary epithelium that originate from other body tissues. Insulin-like growth factor-I contributes significantly to mitogenic activity from both systemic and mammary sources, together with its multiple interactions with other growth factors. Regardless of the source of the mitogenic activity, local mammary synthesis of IGFBP-3 probably influences the growth response of the developing mammary epithelium to IGF-I and other mitogens. The physiological regulation of IGFBP-3 synthesis and the interactions that may exist between IGFBP-3 and other growth factors in the mammary gland remain unclear.

\section{Acknowledgements}

The authors appreciate the assistance of C J Juhl, A K Nielsen, I L Sørensen and L R Norup in primary cell preparation and culture.

\section{References}

Akers RM 1985 Lactogenic hormones: binding sites, mammary growth, secretory cell differentiation and milk biosynthesis in ruminants. Journal of Dairy Science 68 501-519.

Baumrucker CR \& Stemberger BH 1989 Insulin and insulin-like growth factor-I stimulate DNA synthesis in bovine mammary tissue in vitro. Journal of Animal Science 67 3503-3514.

Campbell PG, Skaar TC, Vega JR \& Baumrucker CR 1991 Secretion of insulin-like growth factor-I (IGF-I) and IGF-binding proteins from bovine mammary tissue in vitro. Journal of Endocrinology $\mathbf{1 2 8}$ 219-228.

Collier RJ, McGrath MF, Byatt JC \& Zurfluh LL 1993 Regulation of bovine mammary growth by peptide hormones: involvement of receptors, growth factors and binding proteins. Livestock Production Science 35 21-33.

Cullen KJ, Allison A, Martire I, Ellis M \& Singer C 1992 Insulin-like growth factor expression in breast cancer epithelium and stroma. Breast Cancer Research and Treatment 22 21-29.

D'Ercole J \& Wilkins JR 1984 Affinity labeled somatomedinC-binding proteins in rat sera. Endocrinology 114 1141-1144.

Forsyth IA 1991 The mammary gland. Bailliere's Clinical Endocrinology and Metabolism 5 809-832.

Forsyth IA 1996 The insulin-like growth factor and epidermal growth factor families in mammary cell growth in ruminants: action and interaction with hormones. Journal of Dairy Science 79 1085-1096.

Forsyth IA, Taylor JA \& Moorby CD 1998 DNA synthesis by ovine mammary alveolar epithelial cells: effects of heparin, epidermal growth factor-related peptides and interaction with stage of pregnancy. Journal of Endocrinology 156 283-290.

Hardouin S, Hossenlopp P, Segovia B, Seurin D, Portolan G, Lassarre C \& Binoux M 1987 Heterogeneity of insulin-like growth factor binding proteins and relationships between structure and affinity. I. Circulating forms in man. European Journal of Biochemistry 170 121-132.

Hossenlopp P, Seurin C, Segovia-Quinson B, Hardouin S \& Binoux M 1986 Analysis of serum insulin-like growth factor binding proteins using western blotting: use of the method for titration of binding proteins and competitive binding studies. Analytical Biochemistry 154 138-143.

Hovey RC, Davey HW, Mackenzie DDS \& McFadden TB 1998 Ontogeny and epithelial-stromal interactions regulate IGF expression in the ovine mammary gland. Molecular and Cellular Endocrinology 136 139-144.

Jones JI \& Clemmons DR 1995 Insulin-like growth factors and their binding proteins: biological actions. Endocrine Reviews 16 3-34.

Kleinberg DL 1997 Early mammary development: growth hormone and IGF-I. Journal of Mammary Gland Biology and Neoplasia 2 49-57.

Koff MD \& Plaut K 1995 Expression of transforming growth factor- $\alpha$-like messenger ribonucleic acid transcripts in the bovine mammary gland. Journal of Dairy Science 78 1903-1908. 
McFadden TB, Daniel TE \& RM Akers 1990 Effects of plane of nutrition, growth hormone and unsaturated fat on mammary growth in prepubertal lambs. Journal of Animal Science $\mathbf{6 8}$ 3171-3179.

McGrath MF, Collier RJ, Clemmons DR, Busby WH, Sweeny CA \& Krivi GG 1991 The direct in vitro effect of insulin-like growth factors (IGFs) on normal bovine mammary cell proliferation and production of IGF binding proteins. Endocrinology 129 671-678.

Mondschein JS, Canning SF, Miller DQ \& Hammond JM 1989 Insulin-like growth factors (IGFs) as autocrine/paracrine regulators of granulosa cell differentiation and growth: studies with a neutralizing monoclonal antibody to IGF-I. Biology of Reproduction 40 79-85.

Norup LR \& Vestergaard M 1996 Use of the Octeia IGF-I assay for bovine and porcine samples. In Endokrin Regulering Af Yverudviklingen Hos Kvier (in Danish). Norup LR: MSc Thesis, Aarhus University, April 1997.

Oka T, Yoshimura M, Lavandero S, Wada K \& Ohba Y 1991 Control of growth and differentiation of the mammary gland by growth factors. Journal of Dairy Science 74 2788-2800.

Peri I, Shamay A, McGrath MF, Collier RJ \& Gertler A 1992 Comparative mitogenic and galactopoietic effects of IGF-I, IGF-II and des-3-IGF-I in bovine mammary gland in vitro. Cell Biology International Reports 16 359-368.

Purup S, Sandowski Y \& Sejrsen K 1995 Endocrine effect of IGF-I on mammary growth in prepubertal heifers. In Intercellular Signalling in the Mammary Gland, pp 93-94. Eds CJ Wilde, M Peaker \& CH Knight. New York: Plenum Press Ltd.

Purup S, Vestergaard M, Weber MS, Plaut K, Akers RM \& Sejrsen K 1999 Local regulation of pubertal mammary growth in heifers. Journal of Animal Science (In Press).

Romagnolo D, Akers RM, Byatt JC, Wong EA \& Turner JD 1994 IGF-I-induced IGFBP-3 potentiates the mitogenic actions of IGF-I in mammary epithelial MD-IGF-I cells. Molecular and Cellular Endocrinology 102 131-139.

Sandowski Y, Peri I \& Gertler A 1993 Partial purification and characterization of putative paracrine/autocrine bovine mammary epithelium growth factors. Livestock Production Science 35 35-48.

SAS Institute, Inc. 1989. Cary, NC.

Sejrsen K, Foldager J, Sorensen MT, Akers RM \& Bauman DE 1986 Effect of exogenous bovine somatotropin on pubertal mammary development in heifers. Journal of Dairy Science 69 1528-1535.
Shamay A \& Gertler A 1986 A model for in vitro proliferation of undifferentiated bovine mammary epithelial cells. Cell Biology International Reports 10 923-927.

Shamay A, Cohen N, Niwa M \& Gertler A 1988 Effect of insulinlike growth factor-I on deoxyribonucleic acid synthesis and galactopoiesis in bovine undifferentiated and lactating mammary tissue in vitro. Endocrinology 123 804-809.

Vestergaard M, Purup S \& Sejrsen K 1995 Influence of bovine growth hormone and feeding level on growth and endocrine status of prepubertal heifers. Journal of Animal Science 73 (Suppl 1) 148.

Waksman M, Shamay A \& Gertler A 1991 Bovine pituitary, kidney, uterine and mammary gland extracts contain bovine mammary epithelium growth factors that synergise with IGF-I and fetal calf serum: indication for involvement of GTP-binding proteins. Domestic Animal Endocrinology 8 271-280.

Weber MS, Purup S, Sejrsen K \& Akers RM 1996 Effects of feeding level and exogenous bST on mammary IGF-I and IGFBP-3 expression in prepubertal dairy heifers. Journal of Dairy Science $\mathbf{7 9}$ (Suppl) 261.

Weber MS, Boyle PB, Corl BA, Wong EA, Gwazdauskas FC \& Akers RM 1998 Expression of ovine insulin-like growth factor-I (IGF-I) stimulates alveolar bud development in mammary glands of transgenic mice. Endocrine 8 251-259.

Winder SJ, Turvey A \& Forsyth IA 1989 Stimulation of DNA synthesis in cultures of ovine mammary epithelial cells by insulin and insulin-like growth factors. Journal of Endocrinology 123 319-326.

Woodward TL, Akers RM \& Turner JD 1994 Lack of mitogenic response to EGF, pituitary and ovarian hormones in bovine mammary epithelial cells. Endocrine 2 529-535.

Zurfluh LL, Bolten SL, Byatt JC, McGrath MF, Tou JS, Zupec ME \& Krivi GG 1990 Isolation of genomic sequence encoding a biologically active bovine TGF- $\alpha$ protein. Growth Factors $\mathbf{3}$ 257-266.

Received 12 June 1998

Revised manuscript received 4 November 1998 Accepted 26 January 1999 